\title{
Multimarker Analysis of Circulating Tumor Cells in Peripheral Blood of Metastatic Breast Cancer Patients: A Step Forward in Personalized Medicine
}

\author{
Andreia de Albuquerque ${ }^{a, b}$ Sepp Kaul ${ }^{b}$ Georg Breier ${ }^{a} \quad$ Petra Krabisch $^{c}$ Nikos Fersis $^{c}$ \\ ${ }^{a}$ Department of Pathology, Faculty of Medicine Carl Gustav Carus, University of Dresden,

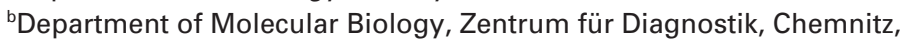 \\ 'Department of Gynaecology and Obstetrics, Klinikum Chemnitz, Germany
}

\begin{abstract}
Keywords
Circulating tumor cells - Metastatic breast cancer . Immunomagnetic separation - Real-time reverse transcription-polymerase chain reaction . Gene expression analysis
\end{abstract}

\section{Summary}

Aim: To develop an immunomagnetic assay for the isolation of circulating tumor cells (CTCs) followed by the analysis of a multimarker panel, which will enable the characterization of these malignant cells with high accuracy. Patients and Methods: Peripheral blood (PB) was collected from 32 metastatic breast cancer patients and 42 negative controls. The antibodies BM7 and VU1D9 were used for immunomagnetic tumor cell enrichment. A real-time reverse transcription-polymerase chain reaction (RT-PCR) approach for the markers KRT19, SCGB2A2, MUC1, EPCAM, BIRC5 and ERBB2 was used for CTC detection and characterization. Results: The positivity rates for each marker were as follows: $46.9 \%$ for KRT19, 25.0\% for SCGB2A2, 28.1\% for MUC1, 28.1\% for EPCAM, $21.9 \%$ for BIRC5, and $15.6 \%$ for ERBB2. After the creation of individualized cutoffs, the sensitivity and specificity of the combined marker gene panel increased to $56.3 \%$ and $100 \%$, respectively. Interestingly, $27.0 \%$ of the HER2-negative tumor patients showed ERBB2 mRNApositive CTCs. Conclusions: The described technique can be used to measure CTCs with great accuracy. The use of a multimarker panel for the characterization of CTCs may provide real-time information and be of great value in therapy monitoring.

\author{
Schlüsselwörter \\ Tumorzellen, zirkulierende - Mammakarzinom, \\ metastatisches · Immunomagnetische Zellisolierung • \\ Real-Time Reverse Transkription Polymerase- \\ Kettenreaktion - Genexpressionsanalyse
}

\section{Zusammenfassung}

Ziel: Entwicklung eines immunomagnetischen Verfahrens zur Isolierung zirkulierender Tumorzellen (CTCs) in Kombination mit einer molekularen Multimarkeranalyse für die hochspezifische Identifizierung maligner Zellen. Patientinnen und Methoden: Peripheres Blut (PB) von 32 Patientinnen mit metastasiertem Mammakarzinom und von 42 gesunden Kontrollen wurde für die immunomagnetische Tumorzellanreicherung mit den Antikörpern BM7 und VU1D9 genutzt. Eine Real-Time Reverse Transkription Polymerase-Kettenreaktion (RT-PCR)Methodik mit den Markern KRT19, SCGB2A2, MUC1, EPCAM, BIRC5 und ERBB2 wurde für den CTC-Nachweis und die Tumorzellcharakterisierung entwickelt. Ergebnisse: Für die einzelnen Marker wurden die folgenden Positivitätsraten ermittelt: 46,9\% für KRT19, 25,0\% für SCGB2A2, 28,1\% für MUC1, 28,1\% für EPCAM, 21,9\% für BIRC5 und 15,6\% für ERBB2. Nach der Bestimmung individualisierter Cut-off-Werte ergab sich für den kombinierten Multimarkernachweis eine Sensitivität und Spezifität von $56,3 \%$ bzw. $100 \%$. Bemerkenswert war der Befund, dass 27,0\% der HER2-tumornegativen Patientinnen ERBB2-mRNA-positive CTCs aufwiesen. Schlussfolgerung: Die hier beschriebene Methodik bestimmt CTCs mit hoher Spezifität. Die molekulare Multimarkeranalyse liefert wertvolle Real-Time-Informationen für personalisierte Behandlungsmodalitäten. 


\section{Introduction}

Breast cancer (BC) is one of the most common diagnosed malignancies in women, being the second leading cause of cancer-related deaths in the female population worldwide [1]. Despite improvements and significant advances in BC treatment and screening, still 5\% of the patients exhibit clinically detectable metastatic lesions and 30-40\% have occult metastases that will possibly lead to a bad prognosis and disease relapse [2].

Women with metastatic $\mathrm{BC}(\mathrm{MBC})$ represent a heterogeneous group with varying prognosis. However, even if attempts have been made to stratify MBC patients into various prognostic groups using traditional prognostic indices, these data are often limited and not accurate enough to predict survival rates [3] considering that breast tumors are characterized by their heterogeneity. In addition, it is also well known that systemic chemotherapy is toxic and in some cases of low effectivity $[4,5]$. Therefore, it is important to develop novel methods that would allow the proper selection of patients for a given type of systemic treatment and predict their outcome [6].

Prospective studies have demonstrated that detection of circulating tumor cells (CTCs) in MBC can successfully predict progression-free survival (PFS) and overall survival (OS) $[7,8]$. CTCs are tumor cells that can detach from the primary tumor, extravasate, circulate into the bloodstream, reach distant organs and potentially give rise to metastasis [9]. Indeed, CTCs provide a link between the primary tumor and the metastatic lesions, which may contain precious information. However, isolation of CTCs has proven to be difficult since these malignant cells are rare events occurring at rates as low as 1 cell per $10^{5}-10^{7}$ peripheral blood (PB) mononucleated cells [10]. Several methods have been developed to detect CTCs in the blood of patients with different malignant carcinomas, with each one having unique advantages and limitations. However, no enrichment or detection method has yet proven to be the golden standard, and continuing efforts are needed to improve the sensitivity and reliability of CTC detection techniques. One of the most common techniques available for the isolation of CTCs relies on the separation of specific cell subsets in a magnetic field when they are labeled by specific antibodies conjugated with magnetic particles - immunomagnetic separation - followed by real-time reverse transcription-polymerase chain reaction (real-time RT-PCR), a technique that provides a high analytical sensitivity, by enabling the detection of a single tumor cell among $10^{7}$ normal cells [11]. In addition to detection and enumeration, molecular characterization of CTCs provides a very promising application in oncology. The tumor phenotype can change during the course of the disease, and CTCs might function as real-time biopsies [12-14]. These observations led us to conduct this pilot study, which aims to develop an immunomagnetic assay for the isolation of CTCs, followed by the analysis of a tumor-specific marker gene panel using real-time RTPCR; this will enable the characterization of these malignant cells and perhaps contribute to a more individualized treatment approach. The selected marker panel comprises the following genes: KRT19, SCGB2A2, MUC1, EPCAM, BIRC5, and $E R B B 2$. Extensive assay validation experiments were conducted in order to address technical concerns, such as specificity, sensitivity and efficiency, and to obtain the highest accuracy for the assay.

\section{Patients and Methods}

\section{Patients}

Clinically confirmed MBC patients were recruited. The study was approved by the local ethics committee (ethic-vote 473-2006 and DETECT 2007) and was conducted in concordance with the declaration of Helsinki. All patients enrolled provided their written informed consent.

\section{PB Sampling}

From all MBC patients, 10.0-ml whole blood samples were collected, before treatment, during routine blood sampling into ethylenediaminetetraacetic acid (EDTA) tubes (Sarstedt AG and Co, Nümbrecht, Germany), and the CTCs were isolated within $4 \mathrm{~h}$ of specimen collection. A group of 42 healthy, anonymous control subjects, who were randomly selected from the hospital staff, were asked to participate in the study, and blood sampling was performed as described above.

\section{Cell Culture}

The tumor cells lines T47D, MCF7 and SKBR3, obtained from the American Type Culture Collection, and the human breast carcinoma cell line ZE, obtained by isolation of a primary tumor tissue (T3, N2, G3, HER2 3 plus) after 15-20 culture passages, having a HER2 gene amplification level of $>5$ (determined by fluorescence in situ hybridization (FISH)) and being surprisingly homogeneous in the expression of several breast tumor-associated genes including KRT19, SCGB2A2, MUC1, EPCAM, $B I R C 5$, and $E R B B 2$, were used in this study. The cells were preserved and cultured in $75-\mathrm{cm}^{2}$ tissue culture flasks using Dulbecco's modified Eagle medium (DMEM; Invitrogen, Karlsruhe, Germany) supplemented with $8 \%$ fetal calf serum (FCS), $0.5 \%$ penicillin-streptomycin, at $37{ }^{\circ} \mathrm{C}$ in a $5 \% \mathrm{CO}_{2}$ environment. Log phase cells were collected at $<90 \%$ confluence by trypsin digestion and used for spiking and dilution experiments.

\section{Embedded Tumor Cell Calibrators}

In order to control the efficiency and robustness of the assay, $10 \mathrm{ZE}$ tumor cells were spiked into matching calibrator probes and negative donor probes by microscope-controlled micromanipulation. These calibration tests were performed routinely and spiked probes were analyzed by real-time RT-PCR for the marker genes KRT19, SCGB2A2, MUC1, $E P C A M, B I R C 5$, and $E R B B 2$.

\section{Immunomagnetic Enrichment Antibodies}

In this assay, two antibodies were used for immunomagnetic separation of CTCs in PB: the commercially available VU1D9, a high-affinity antibody reactive with a fixation-resistant epitope of the membrane protein EpCAM, and our own antibody BM7 [15], the epitope of which is the glycopeptide APDTRPAP, substituted with $\mathrm{N}$-acetylgalactosamine on the threonine of the tandem repeat structure of the tumor-associated underglycosylated mucin-1. 


\section{CTC Isolation from Blood Samples}

CTCs were isolated from PB using $200 \mu \mathrm{L}$ of BM7/VU1D9 antibodies coupled directly to immunomagnetic 4-micron Dynabeads ${ }^{\circledR}$ (Invitrogen, Karlsruhe, Germany). The beads were incubated with the PB on a lowspeed rotating device for $20 \mathrm{~min}$ at room temperature, after which the labeled cells were separated using an external magnetic particle concentrator (MPC). The bead fraction was washed 5 times with phosphate-buffered salt solution (PBS) and the retained mucin-1+ and/or EpCAM+ cells were lysed in $400 \mu \mathrm{l}$ Tris- $\mathrm{HCl}$ lysis buffer (included in the Dynabeads ${ }^{\circledR}$ mRNA Direct ${ }^{\mathrm{TM}}$ kit; Invitrogen, Karlsruhe, Germany) and stored at $-85^{\circ} \mathrm{C}$ until mRNA isolation and cDNA synthesis.

\section{$m R N A$ Isolation and $c D N A$ Synthesis}

mRNA isolation from the lysed enriched cells was performed with the Dynabeads $^{\circledR}$ mRNA DIRECT ${ }^{\mathrm{TM}}$ kit according to the manufacturer's instructions. Sensiscript ${ }^{\circledR}$ Reverse Transcriptase (Qiagen, Hilden, Germany), recommended for first-strand cDNA synthesis using $<50 \mathrm{ng}$ RNA, was used for reverse transcription of the isolated and purified mRNA in combination with the Dynabeads ${ }^{\circledR}$ oligo $(\mathrm{dT})_{25}$ primer (Invitrogen, Karlsruhe, Germany), according to the manufacturer's guidelines. Reverse transcription was performed in $0.5 \mu \mathrm{l}$ RNasin ${ }^{\circledR}$ ribonuclease inhibitor (40 U/ $\mu$ l; Promega, Mannheim, Germany), $4 \mu \mathrm{l}$ RT buffer, $4 \mu \mathrm{l}$ dNTPs ( $5 \mathrm{mM}$ each), $2 \mu \mathrm{l}$ Sensiscript reverse transcriptase, in a thermocycler under the following conditions: $60 \mathrm{~min}$ at $37{ }^{\circ} \mathrm{C}$ followed by $5 \mathrm{~min}$ at $93{ }^{\circ} \mathrm{C}$. The resulting $40 \mu \mathrm{l}$ of $\mathrm{cDNA}$ was stored at $-20^{\circ} \mathrm{C}$ until further use.

\section{Multimarker Real-Time PCR Analysis}

Reverse transcription resulted in cDNA, which was the template for tumor cell detection and characterization by real-time PCR. The analysis of tumor-associated mRNA isolated from CTCs was performed for KRT19, SCGB2A2, MUC1, EPCAM, BIRC5, and ERBB2. Primers were selected using the Universal ProbeLibrary ${ }^{\circledR}$ system, and their sequences can be seen in table 1 . The selected primers were designed to be intron spanning (exon specific), to eliminate reactivity with genomic DNA. The amplification of $A C T B$ (primers: forward 5'-GAAGAGCCAAGGACAGGTAC-3'; reverse 5'-CAACTTCATCCACGTTCACC-3') served as a reference internal control and was used to verify the integrity of the RNA and the quality of the samples. PCR amplifications were performed on the Rotor-Gene 3000 in a total volume of $25 \mu$ l. Each reaction contained $12.5 \mu \mathrm{l}$ reaction buffer MESA FAST qPCR MasterMix Plus for SYBR $^{\circledR}$ assay (Eurogentec, Köln, Germany), including dNTPs (together with dUTP), MeteorTaq DNA polymerase, $\mathrm{MgCl}_{2}$ (4 $\mathrm{mM}$ final concentration), SYBR ${ }^{\circledR}$ Green I and stabilizers, $0.1 \mu$ of each primer $(100 \mathrm{pmol} /$ $\mu \mathrm{l}), 2 \mu \mathrm{l}$ cDNA and $10.3 \mu \mathrm{l}$ of RNase-free $\mathrm{H}_{2} \mathrm{O}$. The thermal profile used for real-time PCR was as follows: After a 5-min denaturation step at $95^{\circ} \mathrm{C}, 40$ cycles were carried out by denaturation at $95{ }^{\circ} \mathrm{C}$ for $5 \mathrm{~s}$, annealing at $59{ }^{\circ} \mathrm{C}$ for $20 \mathrm{~s}$ and extension for $12 \mathrm{~s}$ at $72{ }^{\circ} \mathrm{C}$. Cell line cDNA was included as a positive control for the evaluation of the PCR reaction and positivity of the tumor-associated transcripts.
PCR efficiency, linearity and sensitivity of each gene was validated with a standard curve constructed from a simultaneously run serially diluted cDNA pool of human PB lymphocytes (PBL) and the tumor cell line $\mathrm{ZE}$, which expresses all the gene markers analyzed in this assay. Negative controls included samples without reverse transcriptase and samples where the cDNA was replaced with genomic DNA. All values were obtained from the quantitative cycle $(\mathrm{Cq})$ at which the increase in SYBR green fluorescent signal associated with an exponential increase of PCR products reached the fixed threshold value of 0.25 .

Random PCRs were analyzed by gel electrophoresis in order to determine the specificity of the assay and to ensure that, under the PCR conditions and with the different primer sets used, the product of the expected size was amplified.

\section{Marker Gene Cutoff}

In this study, 6 marker genes that are known to be overexpressed in breast cancer and other adenocarcinoma types [16-18] were selected based on literature relevance, and their expression in CTCs was analyzed through real-time PCR. However, in order to obtain accurate results, information about the analytical sensitivity of the assay must be established. Therefore, to determine the analytical limit of detection, serial 10-fold dilutions of a cDNA pool of human PBL and $\mathrm{ZE}$ tumor cells were used to construct standard curves. Dilutions were tested in quintuplicate and the corresponding $\mathrm{Cq}$ value obtained as the lower analytical limit of detection for each gene was selected as the analytical cutoff.

\section{Statistical Analysis}

The linearity, efficiency and analytical sensitivity of the real-time RTPCR assay were assessed by linear regression analysis. Standard curves were constructed for each marker, and from the equation obtained after regression analysis, the following parameters were determined: sensitivity, given by the y-intercept; linearity, expressed as the correlation coefficient $\left(\mathrm{R}^{2}\right)$; and efficiency of the assay, determined by the slope of the loglinear phase of the amplification reaction. All data were analyzed using SPSS $^{\circledR}$ (version 17.0; SPSS, Chicago, IL, USA).

\section{Results}

\section{Assay Validation}

To determine the linearity, efficiency and analytical sensitivity of the multimarker real-time RT-PCR assay, we analyzed serial 10-fold dilutions of a cDNA pool of human PBL and ZE tumor cells, in 5 different experiments for the 5 tumor-associated transcripts: KRT19, SCGB2A2, MUC1, EPCAM, $B I R C 5$, and $E R B B 2$. The calibration curves from these data showed linearity over the entire quantification range $\left(1-10^{4}\right.$

Table 1. Primer sequences of the 6 tumor-associated transcripts

\begin{tabular}{|c|c|c|c|c|}
\hline Marker & NM reference & Primer sequence & Location & Product size \\
\hline KRT19 & NM_002276.2 & $\begin{array}{l}\text { forward: GCCACTACTACACGACCATCC } \\
\text { reverse: CAAACTTGGTTCGGAAGTCAT }\end{array}$ & $\begin{array}{l}525-545, \text { exon } 1 \\
650-630, \text { exon } 2 / 3\end{array}$ & $126 \mathrm{bp}$ \\
\hline$S C G B 2 A 2$ & NM_002411.21 & $\begin{array}{l}\text { forward: CTCCCAGCACTGCTACGC } \\
\text { reverse: TGTGGATTGTCTTGGAAA }\end{array}$ & $\begin{array}{l}95-112, \text { exon } 1 \\
158-145, \text { exon } 2\end{array}$ & 72 bp \\
\hline$M U C 1$ & NM_002456.4 & $\begin{array}{l}\text { forward: TCGTAGCCCCTATGAGAAGG } \\
\text { reverse: CCACTGCTGGGTTTGTGTAA }\end{array}$ & $\begin{array}{l}795-814, \text { exon } 7 / 8 \\
865-846, \text { exon } 8\end{array}$ & $71 \mathrm{bp}$ \\
\hline EPCAM & NM_002354.2 & $\begin{array}{l}\text { forward: CGTCAATGCCAGTGTACTTCA } \\
\text { reverse: TTTCTGCCTTCATCACCAAA }\end{array}$ & $\begin{array}{l}448-508, \text { exon } 2 \\
575-553, \text { exon } 3\end{array}$ & 88 bp \\
\hline BIRC5 & NM_001168.2 & $\begin{array}{l}\text { forward: GCCCAGTGTTTCTTCTGCTT } \\
\text { reverse: CCGGACGAATGCTTTTTATG }\end{array}$ & $\begin{array}{l}284-303, \text { exon } 2 \\
369-350, \text { exon } 3\end{array}$ & 86 bp \\
\hline$E R B B 2$ & NM_004448.2 & $\begin{array}{l}\text { forward: GGGAAACCTGGAACTCACCTA } \\
\text { reverse: CCCTGCACCTCCTGGATA }\end{array}$ & $\begin{array}{l}409-429, \text { exon } 2 \\
483-466, \text { exon } 3\end{array}$ & $75 \mathrm{bp}$ \\
\hline
\end{tabular}


tumor cells) and $\mathrm{R}^{2} \geq 0.99$ in all of the cases, indicating a precise log-linear relationship. The PCR efficiency, expressed as $\mathrm{E}=10^{-1 / \text { slope }}$ ranged from 96 to $104 \%$ for the multimarker panel. The analytical sensitivity was estimated as the last serial linear concentration that yielded positives in all 5 replicates, and the corresponding $\mathrm{Cq}$ value was selected as the analytical cutoff. According to the results obtained, the analytical $\mathrm{Cq}$ cutoff under which a sample is considered to be positive for the corresponding marker gene was defined as: 36.0 for KRT19, 37.3 for $S C G B 2 A 2,37.1$ for $M U C 1,36.0$ for $E P C A M, 35.0$ for $B I R C 5$, and 37.9 for $E R B B 2$.

\section{Embedded Tumor Cell Calibrator Results}

Tumor cells from one cell line of a primary breast carcinoma (ZE) and from established cell lines - T47D, MCF7 and SKBR3 - were spiked into blood from negative controls and matched calibrator samples in order to evaluate the efficiency and robustness of the assay. We analyzed 60 samples spiked with 2 tumor cells and 40 samples spiked with 10 tumor cells. All tumor cells were reliably identified at the level of 10 tumor cells in $5 \mathrm{ml}$ of blood, and the detection rate for 2 tumor cells in $5 \mathrm{ml}$ of blood was $92 \%$.

\section{Patients' Samples}

Blood samples were obtained from $32 \mathrm{MBC}$ patients, according to a standardized procedure. The inclusion criteria were as follows: women with histological diagnosis of breast cancer, evidence of metastatic disease from imaging studies, starting a new line of therapy, and/or already treated for the advanced disease. Line and type of therapy were not used as selection criteria in this study. The demographic data and the clinicopathological characteristics of all patients are summarized in table 2 .

\section{Expression of the Multimarker Panel in MBC Patients}

A total of $56.3 \%$ of the analyzed MBC patients had a positive signal in at least 1 cancer-associated marker gene in their PB sample. Individualized gene positivity rates were as follows: $46.9 \%$ for $K R T 19,25.0 \%$ for $S C G B 2 A 2,28.1 \%$ for $M U C 1$, $28.1 \%$ for $E P C A M, 21.9 \%$ for BIRC5, and $15.6 \%$ for $E R B B 2$. No amplification of the marker genes was seen in the 42 analyzed healthy controls. Interestingly, $27.0 \%$ of the patients with HER2-negative tumors had ERBB2 mRNA-positive CTCs, and patients among the same prognostic groups showed different CTC marker profiles. A detailed description of the marker positivity according to site of metastasis and receptor status can be seen in figure 1 .

\section{Discussion}

In the present study, we developed an immunomagnetic assay for the isolation of CTCs, followed by the analysis of a tumorspecific marker gene panel using real-time RT-PCR, which
Table 2. Demographic and clinical description of the MBC patients

\begin{tabular}{|c|c|c|}
\hline \multirow{2}{*}{ Variable } & \multicolumn{2}{|c|}{ Breast patients } \\
\hline & $\mathrm{n}$ & $\%$ \\
\hline Total number of patients & 32 & \\
\hline \multicolumn{3}{|l|}{ Age at study entry, years } \\
\hline Median & 60.6 & \\
\hline Range & $41-80$ & \\
\hline \multicolumn{3}{|l|}{ Tumor size } \\
\hline $\mathrm{T} 1$ & 6 & 18.8 \\
\hline $\mathrm{T} 2$ & 15 & 46.9 \\
\hline $\mathrm{T} 3$ & 5 & 15.6 \\
\hline $\mathrm{T} 4$ & 3 & 9.4 \\
\hline Unknown & 3 & 9.4 \\
\hline \multicolumn{3}{|l|}{ Lymph nodes } \\
\hline No & 9 & 28.1 \\
\hline$\geq \mathrm{N} 1$ & 20 & 62.5 \\
\hline Unknown & 3 & 9.4 \\
\hline \multicolumn{3}{|l|}{ Histology grade } \\
\hline G1 & 2 & 6.3 \\
\hline G2 & 15 & 46.9 \\
\hline G3 & 11 & 34.4 \\
\hline Unknown & 4 & 12.5 \\
\hline \multicolumn{3}{|l|}{ Histology } \\
\hline Ductal & 13 & 40.6 \\
\hline Lobular & 6 & 18.8 \\
\hline Other & 4 & 12.5 \\
\hline Unknown & 9 & 28.1 \\
\hline \multicolumn{3}{|l|}{ Site of metastasis at study entry ${ }^{\mathrm{a}}$} \\
\hline Visceral & 9 & 28.1 \\
\hline Nonvisceral & 14 & 43.8 \\
\hline Both & 9 & 28.1 \\
\hline \multicolumn{3}{|l|}{ Receptor status } \\
\hline ER and/or PR positive & 16 & 50.0 \\
\hline HER2 positive/ER/PR negative & 9 & 28.1 \\
\hline ER/PR/HER2 negative & 6 & 18.8 \\
\hline
\end{tabular}

${ }^{a}$ Visceral sites included lung, liver, brain, adrenal glands, pancreas and pleura (with or without effusions). Nonvisceral sites included breast, lymph nodes, chest wall, bone, and skin.

$\mathrm{ER}=$ Estrogen receptor, $\mathrm{PR}=$ progesterone receptor.

will enable the characterization of these malignant cells and perhaps will contribute to a more individualized treatment approach. To improve the reliability of CTC analysis by realtime RT-PCR, we performed a preanalytical enrichment using the tumor-specific antibodies VU1D9 and BM7 with high affinity for the antigens EpCAM and mucin-1, respectively, and employed a panel of tumor-associated marker genes. When combining the analyses of the KRT19, SCGB2A2, MUC1, EPCAM, BIRC5, and ERBB2 mRNAs and creating individualized gene cutoffs, a total of $56.3 \%$ MBC patients were found positive for at least 1 mRNA marker, while no amplification of the marker genes was seen in the 42 analyzed healthy controls. Moreover, data obtained from the embedded tumor cell calibrators and dilution experiments showed that tumor cells could be consistently detected at a level as low as 2 cells, indicating that the developed immunomagnetic assay followed by the amplification of a panel of genes using real-time RT-PCR is a feasible and sensitive technique for CTC detection. It is also important to underline that, among the positive patients, even when grouped according to their prognostic indices, there was heterogeneity in marker expression: Not all the samples were positive for the 6 
Expression of 6 marker genes according to receptor status

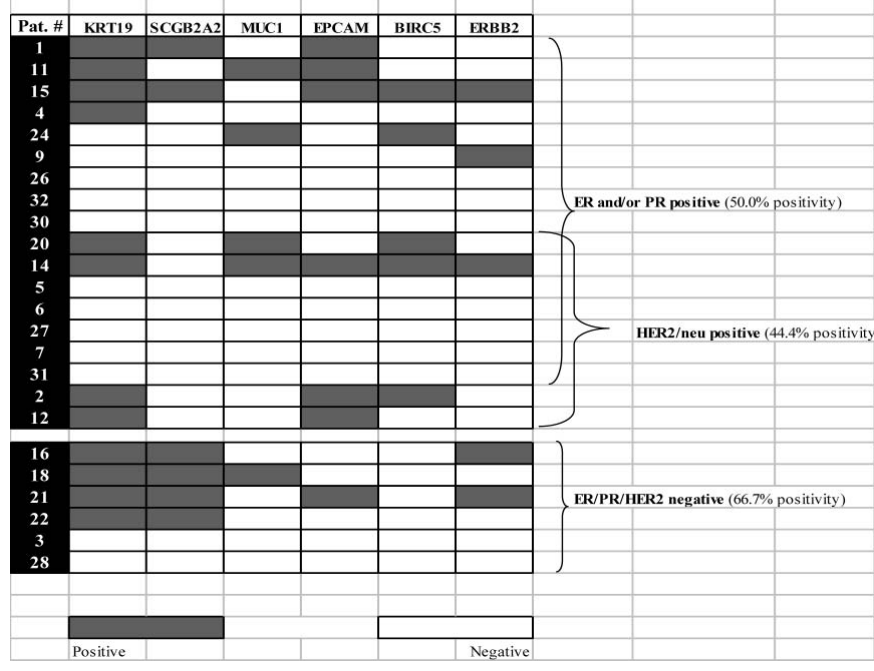

Expression of 6 marker genes according to local of metastasis
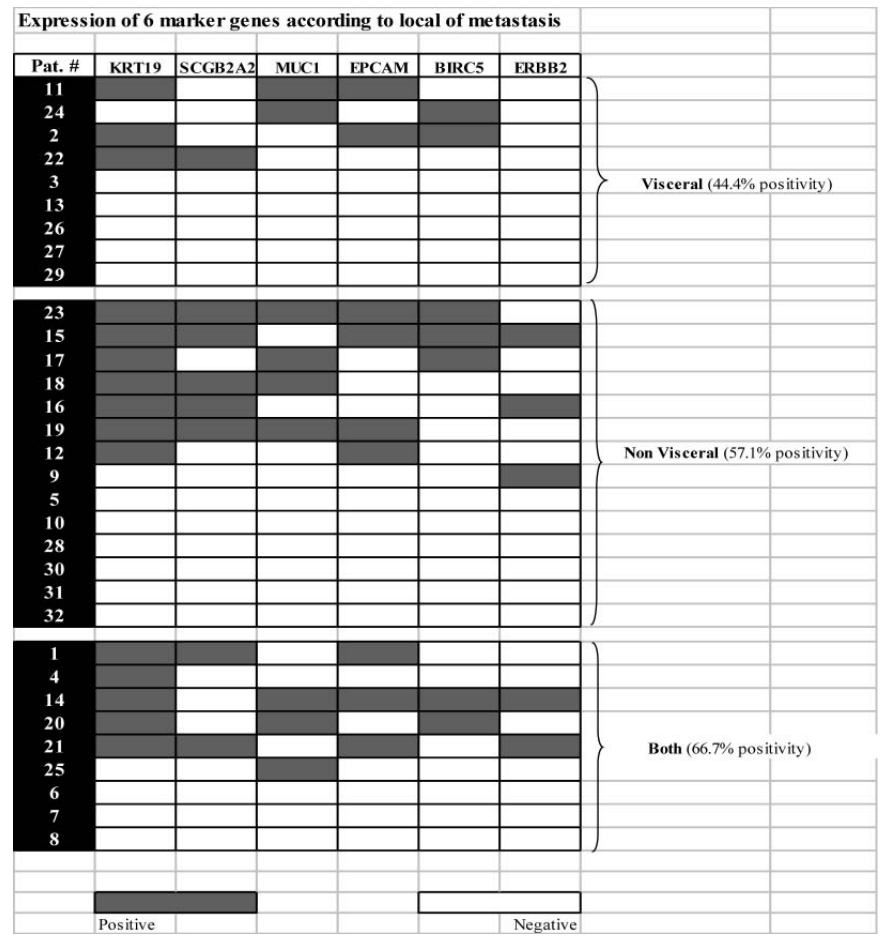

Fig. 1. Marker positivity according to site of metastasis and receptor status.

markers, neither did all the patients exhibit the same positive markers with the same level of expression, and this highlights the need for the use of a multimarker gene panel. However, some markers were not singly expressed in any of the analyzed samples, meaning that their use will not increase the sensitivity of the assay. However, our main goal was to develop an assay that would not only identify CTCs with high specificity and sensitivity, but also to perform a phenotype characterization of these cells. We believe that the future of the CTC analysis relies on the development of assays that are capable of generating CTC molecular profiles that could distinguish CTCs with the capacity to metastasize and/or CTCs that can lead to therapy failure. Therefore, even if not all the markers are needed to achieve the maximum sensitivity for the assay, their inclusion may be extremely relevant once the selected genes used for characterization of the CTCs have been proved by others to be overexpressed in adenocarcinomas and to be indicators of poor prognosis. KRT19, coding for a cytoskeletal component present in normal and cancerous epithelial cells [19], is expressed in the majority of breast carcinomas [20] and has been extensively used as a marker for CTC detection [19], due to its high sensitivity. The expression of $E R B B 2$ was revealed to be often coupled with cytokeratinpositive CTCs, which makes $E R B B 2$ a valid marker for the identification of CTCs [21]. MUC1 has been found to be aberrantly expressed and underglycosylated in many tumor tissues like breast tumors and it is associated with poor prognosis [22]. The EPCAM product is involved in signaling processes, gene regulation, and cellular metabolism [23], appearing to be overexpressed by the majority of human epithelial carcinomas [24]. Indeed, it was shown that EPCAM expression in primary breast cancers was associated with poor clinical outcome, and in vitro studies confirmed that the specific ablation of EPCAM expression using RNA interference results in a dramatic decrease in the invasive potential of breast cancer cell lines [25], making EPCAM a candidate for molecular therapy. Another study has shown that the BIRC5 mRNA measured by real-time RT-PCR in the primary tumor had a strong and independent prognostic value in breast cancer and might be used as a marker to stratify breast cancer patients for better treatment modalities [26].

Several clinicopathological factors such as tumor size, tumor grade, and histological type, HER2/neu overexpression, lymphovascular invasion (LVI) and hormone receptor status are known to have a clear prognostic utility in cancer. However, in the era of targeted therapies, the use of a biological parameter instead of the classical prognostic parameters may better fit to the current clinical challenges [27]. Genetic analyses have shown genetic disparities between the primary tumor and the metastatic lesions. Our study revealed that $27.0 \%$ of the patients with HER2/neu-negative tumors had ERBB2 mRNA-positive CTCs, a fact that supports the previous statement. Therefore, monitoring CTCs seems to be an important tool that might identify women who were initially ineligible for herceptin but who would later qualify for the drug.

The goal of therapy for most patients with MBC is basically palliative. Yet, once a treatment regimen is selected for a patient, it is continued until either toxicity or evidence of progression is identified. Thus, there is a need for improvement of the prognostic tools used in the management of MBC patients $[28,29]$. Metastatic spread represents the ultimate cause of death, and in some cases, patients thought to have a localized disease may in fact present occult metastasis, most likely derived from CTCs, which will lead to disease progression. Following this idea, the detection and analysis of CTCs may play an extremely important role in the diagnosis, prognosis and management of MBC patients. 
Clinical relevance of the gene marker panel used to identify and characterize CTCs can only be achieved through studying a large patient cohort with an adequate follow-up time. Nevertheless, small well-designed studies are of great value if they can quickly provide results that can become part of a preliminary selection in order to further design larger confirmatory studies. During the present study, we have shown that the selected antibodies can in fact isolate CTCs with high consistency and also that the combination of the selected marker genes can identify and characterize the isolated CTCs with great sensitivity, without compromising specificity. Therefore, further studies should be made in order to evaluate the prognostic and predictive value of the presented CTC detection assay.

\section{Disclosure Statement}

The authors declare that they have no competing interests. This work was supported by the Klinikum Chemnitz.

\section{Acknowledgements}

The authors thank the nursing staff for collecting blood specimens. They are also grateful to all the staff members who contributed as negative controls.

\section{References}

1 Liu MC, Shields PG, Warren RD, Cohen P, Wilkinson M, Ottaviano YL, et al.: Circulating tumor cells: a useful predictor of treatment efficacy in metastatic breast cancer. J Clin Oncol 2009;27:5153-5159.

$\checkmark 2$ Amadori A, Rossi E, Zamarchi R, Carli P, Pastorelli D, Jirillo A: Circulating and disseminated tumor cells in the clinical management of breast cancer patients: unanswered questions. Oncology 2009;76:375-386.

3 Dawood S, Broglio K, Valero V, Reuben J, Handy $\mathrm{B}$, Islam R, et al.: Circulating tumor cells in metastatic breast cancer: from prognostic stratification to modification of the staging system? Cancer 2008;113:2422-2430.

4 Greil R: The dark side of the moon - the side effects of therapy in a dynamic era of breast cancer management. Breast Care 2009;4:144-147.

$\checkmark 5$ Citron ML: Dose-dense chemotherapy: principles, clinical results and future perspectives. Breast Care 2008:3:251-255.

6 Gazzaniga P, Naso G, Gradilone A, Cortesi E, Gandini O, Gianni W, et al.: Chemosensitivity profile assay of circulating cancer cells: prognostic and predictive value in epithelial tumors. Int $\mathrm{J}$ Cancer 2010;126:2437-2447.

7 Cristofanilli M, Hayes DF, Budd GT, Ellis MJ, Stopeck A, Reuben JM, et al.: Circulating tumor cells: a novel prognostic factor for newly diagnosed metastatic breast cancer. J Clin Oncol 2005;23:1420-1430.

8 Fehm T, Müller V, Alix-Panabières C, Pantel K: Micrometastatic spread in breast cancer: detection, molecular characterization and clinical relevance. Breast Cancer Res 2008;10(suppl 1):S1.

9 Miller MC, Doyle GV, Terstappen LW: Significance of circulating tumor cells detected by the CellSearch system in patients with metastatic breast colorectal and prostate cancer. J Oncol 2010;2010:617421.

10 Smerage JB, Hayes DF: The measurement and therapeutic implications of circulating tumour cells in breast cancer. Br J Cancer 2006;94:8-12.
11 Bitisik O, Saip P, Saglam S, Derin D, Dalay N: Mammaglobin and maspin transcripts in blood may reflect disease progression and the effect of therapy in breast cancer. Genet Mol Res 2010;9:97-106.

12 Mostert B, Sleijfer S, Foekens JA, Gratama JW: Circulating tumor cells (CTCs): detection methods and their clinical relevance in breast cancer. Cancer Treat Rev 2009;35:463-474.

13 Becker S, Becker-Pergola G, Banys M, Krawczyk $\mathrm{N}$, Wallwiener D, Solomayer E, et al.: Evaluation of a RT-PCR based routine screening tool for the detection of disseminated epithelial cells in the bone marrow of breast cancer patients. Breast Cancer Res Treat 2009;117:227-233.

14 Meng S, Tripathy D, Shete S, Ashfaq R, Haley B, Perkins S, et al.: HER-2 gene amplification can be acquired as breast cancer progresses. Proc Natl Acad Sci USA 2004;101:9393-9398.

15 Lin YS, Zhong XY, Hohaus S, Kaul S, Haas R: Detection of tumor cells in leukapheresis products from patients with breast cancer using immunocytochemical staining method. Arch Gynecol Obstet 2000;263:119-125.

16 de Albuquerque A, Kaul S, Fersis N, Ernst D, Teubner A, Breier G: 1327 Real-time risk evaluation of metastasis using circulating tumor cells. Eur J Cancer 2009;7(suppl 2):147.

17 Ernst D, Teubner A, de Albuquerque A, Kaul S, Fersis N, Boese-Landgraf J: 6104 Circulating tumour cells in colorectal cancer: multi-gene expression analysis during chemotherapy. Eur J Cancer 2009;7(suppl 2):354.

18 Teubner A, Ernst D, de Albuquerque A, Kaul S, Fersis N, Stölzel U: 6636 Genetic profiling of circulating tumor cells in the blood of patients with local advanced or metastatic upper gastrointestinal carcinomas. Eur J Cancer 2009;7(suppl 2):400.

19 Stathopoulou A, Ntoulia M, Perraki M, Apostolaki $\mathrm{S}$, Mavroudis D, Malamos N, et al.: A highly specific real-time RT-PCR method for the quantitative determination of CK-19 mRNA positive cells in peripheral blood of patients with operable breast cancer. Int J Cancer 2006;119:1654-1659.
20 Bartek J, Taylor-Papadimitriou J, Miller N, Millis $\mathrm{R}$ : Patterns of expression of keratin 19 as detected with monoclonal antibodies in human breast tissues and tumours. Int J Cancer 1985;36:299-306.

21 Apostolaki S, Perraki M, Pallis A, Bozionelou V, Agelaki S, Kanellou P, et al.: Circulating HER2 mRNA-positive cells in the peripheral blood of patients with stage I and II breast cancer after the administration of adjuvant chemotherapy: evaluation of their clinical relevance. Ann Oncol 2007;18:851858.

22 Hiraga Y, Tanaka S, Haruma K, Yoshihara M, Sumii K, Kajiyama G, et al.: Immunoreactive MUC1 expression at the deepest invasive portion correlates with prognosis of colorectal cancer. Oncology 1998;55:307-319.

23 Münz M, Zeidler R, Gires O: The tumour-associated antigen EpCAM upregulates the fatty acid binding protein E-FABP. Cancer Lett 2005;225:151157.

24 Osta WA, Chen Y, Mikhitarian K, Mitas M, Salem M, Hannun YA, et al.: EpCAM is overexpressed in breast cancer and is a potential target for breast cancer gene therapy. Cancer Res 2004;64:5818-5824.

25 Sankpal NV, Willman MW, Fleming TP, Mayfield JD, Gillanders WE: Transcriptional repression of epithelial cell adhesion molecule contributes to p53 control of breast cancer invasion. Cancer Res 2009;69:753-757.

26 Span PN, Sweep FCGJ, Wiegerinck ETG, Tjan-Heijnen VCG, Manders P, Beex LVAM, et al.: Survivin is an independent prognostic marker for risk stratification of breast cancer patients. Clin Chem 2004;50:1986-1993.

27 Schütz F: Targeted therapy: Can it substitute for chemotherapy? Breast Care 2008;3:257-261.

28 Harbeck N, Jakesz R, Thomssen C: The future of breast cancer management. Breast Care 2008:3:381-382.

29 Thomssen C: Perspectives on breast cancer management: tailoring treatment to the individual patient. Breast Care 2008;3(suppl 1):21-23. 